IJAMSR 3 (7) www.ijamsr.com CrossRef: https://doi.org/10.31426/ijamsr.2020.3.7.3513

\title{
ANTICANCER ACTIVITY OF MEDICINAL PLANTS: A REVIEW
}

\author{
Vaishnu S S, Jula V, Mahalakshmi M, Senthil J*
}

Department of Microbiology and Biotechnology, Faculty of Arts and Science, Bharath Institute of Higher Education and Research, Chennai, Tamil Nadu, India.

Email: senjana25@gmail.com

Keywords:

Anticancer Activity, Chemotherapy,

Clinical Trials,

Medicinal Plants,

WHO.

\begin{abstract}
A B S T R A C T
Cancer, a major threat and health burden to the existing world. Globally, it severely affects the human population and it is the leading cause of death. Apart from the chemically synthesized drugs, we need to find more drugs from medicinal plants where they are more effective and efficient. Many treatments are being found and tried for the cure of cancer which are mostly tried chemically, instead which we need to discover from medicinal plant. The main goals of WHO on cancer diagnosis and treatment programmes are to cure or considerably prolong the life of patients and to ensure the best possible quality of life for cancer survivors. Plants produce various phytochemicals which have anticancer properties. So medicinal plants play a major role in cure of cancer because they are natural and effective. Natural products are being derived and used for treatment of various diseases since thousands of years in various countries like Egypt, China, India, etc. Plant derived compounds like Taxol, Vinblastine, Vincristine, etc are being used as effective anticancer drugs. Many scientists have found drugs using plant leaf, stem, seed, etc. WHO supports the use of traditional medicines which are effective and non-toxic. Medicinal plants are the future hope for cancer treatments, as the clinical trials using chemical treatments are not much effective and are toxic. Various parts of medicinal plants are being studied and used for clinical trials as anticancer drugs. Medicinal plant treatments are being widely used in India and many countries. This review has focused on various medicinal plants that has reported to possess anticancer properties.
\end{abstract}

Citation: Vaishnu S S, Jula V, Mahalakshmi M, Senthil J* (2020). Anticancer Activity Of Medicinal Plants: A Review. International Journal of Advanced Multidisciplinary Scientific Research (IJAMSR) ISSN:2581-4281, 3 (7), July 2020, Pp 24-29 
IJAMSR 3 (7) www.ijamsr.com CrossRef: https://doi.org/10.31426/ijamsr.2020.3.7.3513

\section{International Journal of \\ Advanced Multidisciplinary Scientific Research (IJAMSR) ISSN:2581-4281}

\section{Introduction}

Cancer can occur in almost any organ or tissue of the body when the uncontrollable growth of abnormal cells occur, go beyond their usual boundaries to invade adjoining parts of the body and spread to other organs. Metastasizing is the latter process and is a major cause of death from cancer. A neoplasm and malignant tumour are other common names for cancer. Cancer is the second leading cause of death worldwide, accounting for an estimated 9.6 million deaths, or one in six deaths, in 2018. Lung, prostate, colorectal, stomach and liver cancer are the most common types of cancer in men, while breast, colorectal, lung, cervical and thyroid cancer are the most common among women. This disease continues to grow exerting tremendous physical, emotional and financial strain on individuals, families, communities and health systems. Many health systems in low and middle income countries are least prepared to manage this burden, and large numbers of cancer patients in the world do not have access to timely quality diagnosis and treatment. In countries where health systems are strong, survival rates of many types of cancers are improving thanks to accessible early detection, quality treatment and survivorship care. There are various types of cancer among which luekemia also called as blood cancer is most dangerous. Many human habits like smoking, drinking, etc has lead to lung cancer, liver cancer, etc. (M Shoeb et al., 2006).

Cure for cancer has not yet been found but clinical trials and treatments using chemicals and chemotherapy has prolonged the life of patients suffering from cancer, so for a better change and cure, scientists are studying on variety of medicinal plants in various countries for a promising drug.

\section{Importance Of Medicinal Plants}

Plant derived drugs are desired for anticancer treatment as they are natural, readily available and they can be orally injested by patients as dietary intake. Naturally derived compounds are non toxic and more tolerable for human cells. However, there are exceptions such as cyanogenetic glycosides, lectins, saponins, lignans, lectins and some taxanes. If plantderived drugs can demonstrate selectivity in research, and are non-toxic to normal cell lines and also show cytotoxicity in cancer cell lines, these drugs are led into clinical trials for further therapeutic development. Plant-derived drugs come under four classes of drugs with 
IJAMSR 3 (7) www.ijamsr.com CrossRef: https://doi.org/10.31426/ijamsr.2020.3.7.3513

\section{International Journal of} Advanced Multidisciplinary Scientific Research (IJAMSR) ISSN:2581-4281

the following activities; methyltransferase inhibitors, DNA damage preventive drugs or antioxidants, histone deacetylases (HDAC) inhibitors and mitotic disruptors.

TABLE 1: LIST OF MEDICINAL PLANTS HAVING ANTICANCER ACTIVITY

\begin{tabular}{|c|c|c|c|}
\hline PLANT NAME & FAMILY & PART USED & REFERENCE \\
\hline Allium wallichii & Amaryllidaceae & Whole Plant & Bhandari et al., 2017 \\
\hline Artemisia annua & Asteraceae & Whole Plant & Efferth et al., 2017 \\
\hline Berberis aristata & Berberidaceae & Stem & Mamatha et al., 2015 \\
\hline Camellia sinesis & Theaceae & Leaf & Kumari et al., 2017 \\
\hline Cedrus deodara & Pinaceae & Bark & Gaidhani et al., 2013 \\
\hline Curcuma longa & Zingiberaceae & Rhizomes & Ooko et al., 2017 \\
\hline Elusine coracana & Poaceae & Seed & Srikanth et al., 2016 \\
\hline Ginkgo biloba & Ginkgoaceae & Leaf & Xiong et al., 2016 \\
\hline Glycyrrhiza glabra & Leguminosae & Root & Zhang et al., 2016 \\
\hline Herba epimedii & Berberidaceae & Leaf & Yong et al., 2017 \\
\hline Nigella sativa & Ranunculaceae & Seed & L.Y.Tu et al., 2016 \\
\hline Ocimum sanctum & Lamiaceae & Leaves & Karthikeyan et al., 1999 \\
\hline Paeonia suffruticosa & Paeoniaceae & Seed & Zhang et al., 2016 \\
\hline Peganum harmala & Zygophyllaceae & Root & Ayoob et al., 2017 \\
\hline Picrorhiza kurroa & Plantaginaceae & Rhizomes & Hemanth et al., 2014 \\
\hline Piper longum & Peparaceae & Fruit & Sawhney et al., 2011 \\
\hline Thymus vulgaris & Lamiaceae & Essential oil & Sertel et al., 2011 \\
\hline Vicia faba & Fabaceae & Seed & Amin et al., 2016 \\
\hline Vitex negundo & Lamiaceae & Leaf & Nandu et al., 2009 \\
\hline
\end{tabular}


IJAMSR 3 (7) www.ijamsr.com CrossRef: https://doi.org/10.31426/ijamsr.2020.3.7.3513

International Journal of Advanced Multidisciplinary Scientific Research (IJAMSR) ISSN:2581-4281

TABLE 2: LIST OF PLANTS IN CLINICAL TRIALS (TO CHECK ANTICANCER ACTIVITY)

\begin{tabular}{|c|c|c|}
\hline PLANT NAME & COMMON NAME & FAMILY \\
\hline Allium sativum & Garlic & Amaryllidaceae \\
\hline Camellia sinensis & Green Tea & Theaceae \\
\hline Catharanthus roseus & Madagascar Periwinkle & Apocynaceae \\
\hline Ocimum basilicum & Great Basil & Lamiaceae \\
\hline Taxus brevifolia & Pacific Yew & Taxaceae \\
\hline Zingiber officinale Rosc. & Ginger & Zingiberaceae \\
\hline
\end{tabular}

When the medicinal plants are subjected to clinical trials, they show a promising effect. World Health Organization (WHO) has defined herbal medicines as finished labelled medicinal product that contain an active ingredient, aerial, or underground parts of the plant or other plant material or combinations. According to a report of $\mathrm{WHO}$, about $80 \%$ of the world population is reported to rely on traditional medicine for their primary health care needs. Even in the developed countries, complementary or alternative medicine is gaining popularity. Herbal drugs possess a long history of its use and better patient tolerance. These are cheaper and easily available in countries like India due to rich agro culture conditions. There is lack of scientific evidence to evaluate safety and efficacy of herbal drugs. The quality of the trial drug has to be tested for batch-to-batch uniformity of the active constituents. It is very difficult to have active and control groups with identical colour, smell and taste of the herbal drug, which cannot be imitated while manufacturing a placebo. These challenges can be reduced or overcome by applying most recent methodologies and guidelines for clinical trials. Since the quality control of herbal medicines is complicated and difficult, relevant and appropriate requirements should be established for the assessment of safety and efficacy for different categorized herbal medicines to reduce cost and expenditure.

\section{Plant Phytochemicals Associated With}

\section{Anticancer Activity}

Modern drug development program based on ayurveda concepts has gained wide acceptance in present healthcare system. Plant derived natural products are nontoxic to normal cells 
IJAMSR 3 (7) www.ijamsr.com CrossRef: https://doi.org/10.31426/ijamsr.2020.3.7.3513

and also better tolerated, hence they gain attention of modern drug discovery. Estimated figures reveal that plant kingdom comprises at least 250,000 species and only 10 percent have been investigated for pharmacological applications. Phytochemicals and their derived metabolites present in root, leaf, flower, stem and bark perform several pharmacological functions in human systems. Alkaloids, flavonoids, phenolics, tannins, glycosides, gums, resins and oils are such responsible elements. These elements or their altered forms have shown significant antitumor potential. Vinblastine, vincristine, taxol, elliptinium, etoposide, colchicinamide,

$10-$ hydroxycamptothecin, curcumol, gossypol, ipomeanol, lycobetaine, tetrandrine, homoharringtonine, monocrotaline, curdione, and indirubin are remarkable phytomolecules in this regard.

\section{CONCLUSION}

Cancer is a dangerous disease and it is incurable if it reaches the last stage since now. But can be controlled or prolong the life of patients by treating with chemical drugs. Now the only hope is herbal drugs from medicinal plants that can cure cancer. There are variety of medicinal plants across world which shows anticancer properties. Various studies are done on wide variety of plants for anticancer activity. The treatment using synthetic drugs are less effective, costly and has side effects while the use of herbal drugs is non-toxic, safe, less expensive and are available as a gift of nature.

\section{References}

1) Denis Mabeya Ogato, Eliakim Mbaka Mauti, Godfrey Omare Mauti, Barasa Ambrose, David Keno Kowanga.,2015. Anticancer activity of Eugenia jambolana seeds against Hep2 cell lines. The Journal of Phytopharmacology, 4(6): 295-298.

2) E.,Ooko, O.,Kadioglu, H.J.,Greten, T.,Efferth., 2017. Pharmacogenomic characterization and isobologram analysis of the combination of ascorbic acid and curcumin - two main metabolites of Curcuma longa - in cancer cells. Front Pharmacol, 8: 38.

3) F., Wu, L.,Zhou, W.,Jin, W., Yang, Y.,Wang, B.,Yan, et al., 2016. Anti-proliferative and apoptosis inducing effect of Theabrownin against non-small cell lung adenocarcinoma A549 cells. Front Pharmacol, 7: 465.

4) I.,Ayoob, Y.M.,Hazari, S.H.,Lone, S.U.,Rehman, M.A.,Khuroo, K.M.,Fazili, K.A.,Bhat, 2017. Phytochemical and Cytotoxic evaluation of Peganum harmala: structure activity relationship studies of harmine. Chemistry Select, 2(10): 2965 2968. 
IJAMSR 3 (7) www.ijamsr.com CrossRef: https://doi.org/10.31426/ijamsr.2020.3.7.3513

\section{International Journal of \\ Advanced Multidisciplinary Scientific Research (IJAMSR) ISSN:2581-4281}

5) J.,Bhandari, B.,Muhammad, P.,Thapa, B.G.,Shrestha., 2017. Study of phytochemical, antimicrobial, anti-oxidant, anticancer properties of Allium wallichii. BMC Compl Altern Med, 17(1): 102.

6) K.,Karthikeyan, P., Gunasekaran, N., Ramamurthy, S.,Govindasamy, 1999. Anticancer activity of Ocimum sanctum. Pharmaceutical Biology, 37(4): 285-290.

7) L.Y.,Tu, J.,Pi, H.,Jin, J.Y.,Cai, S.P.,Deng, 2016. Synthesis, characterisation and anticancer activity of Kaempferol-Zinc (II) complex. Bioorg Med Chem Lett, 26(11): 2730-2734.

8) M.,Hemanth Kumar, C.,Rameshi, 2014. Anticancer activity of nano encapsulated formulation from the extracts of Picrorhiza kurroa against human cancer cell lines. Journal of Pharmacognosy and Phytochemistry, 2(5): 182-185.

9) M.,Kumari, B.,Pattnaik, S.Y.,Rajan, S.,Shrikanth, S.U.,Surendra., 2017. EGCGA promis anticancer. Phytochemistry, 3: 810.

10) M.,Xiong, L.,Wang, H.L.,Yu, H.,Han, D.,Mao, J.,Chen, et al., 2016. Ginkgetin exerts growth inhibitory and apoptotic effects on osteosarcoma cells through inhibition of STAT3 and activation of caspase-3/9. Oncolo Rep, 35(2): 10341040.

11) Mamatha.,S,

Shanmuga.R., C, P.K.,Manikonda, J.R.,Kamala, 2015. Anticancer activity of methonolic extract of Berberis aristata in Mcf-7 human breast cancer lines. International Journal of Life Sciences Biotechnology and Pharma Research, 4(1): 31-35.

12) Mohammad Shoeb.,2006. Anticancer agents from medicinal plants. Bangladesh J Pharmacol, 1: 35-41.

13) Nandu Kayande, Chitra $V$ and Shrinivas Sharma, 2009. Evaluation of Anticancer activity of Vitex negundo in experimental animals: An in vitro and in vivo study.
International Journal of PharmTech Research, 1(4): 1485-1489.

14) Preethi.,R, $\quad$ Padma.,P.R., 2016. Biosynthesis and bioactivity of silver nano bioconjugates from grape (Vitis vinifera) seeds and its active component resveratrol. Int J Pharma Sci Res, 7(10): 4253.

15) S.,Amin, H.K.,Bharkatullah, 2016. Pharmacology of Xanthium species. A review. J Phytopharm, 5: 126-127.

16) S.,Sertel, T.,Eichhorn, P.K.,Plinkert, T.,Efferth, 2011. Cytotoxicity of Thymus vulgaris essential oil towards human oral cavity squamous cell carcinoma. Anticancer Research, 31 (1): 81-87.

17) S.,Srikanth, Z.,Chen, 2016. Plant protease inhibitors in therapeutics-focus on cancer therapy. Front Pharmacol, 7: 470.

18) S.N.,Gaidhani, Arjun Singh, S.,Kumari, M.M.,Padhi, et al, 2013. Evaluation of some plant extracts from standardization and anticancer activity. Indian Journal of Traditional Knowledge, 12(4): 682-687.

19) S.S.,Sawhney, R.M.,Painulf, N.,Chauhan, 2011. Evaluation of bactericidal and anticancer properties of fruits of Piper longum. International Journal of Pharmacy and Pharmaceutical sciences, 3: 282-287.

20) T.,Efferth.,2017. From ancient herb to versatile, modern drug; Artemsia annua and Artemisenin for cancer therapy. Seminars in Cancer Biology, 46: 65-83.

21) Y.L.,Yong, L.T.,Tan, L.C.,Ming, K.G.,Chan, L.H.,Lee, B.H.,Goh, T.M.,Khan, 2017. The effectiveness and safety of topical capsaicin in postherpetic neuralgia : a systematic review and metaanalysis. Front Pharmacol, 7:538.

22) Y.Y.,Zhang, C.T.,Hnang, S.M.,Liu, B.,Wang, J.,Guo, J.Q.,Bai, et al, 2016. Licochalcone A exerts antitumor activity in bladder cancer cell lines and mice models. Trop J Pharm Res, 15(6): 1151-1157. 